\title{
Peningkatan Dalam Penggunaan Media Ular Tangga Mata Kuliah Pendidikan PKn SD Materi Strategi Pembelajaran Pada Kemampuan Kognitif Mahasiswa Semester 2 STKIP Bina Insan Mandiri Surabaya
}

\author{
Noviardani Kartika Prameswari \\ STKIP Bina Insan Mandiri \\ kartikaprameswari88@gmail.com
}

\begin{abstract}
Abstrak
Penelitian ini mengenai peningkatan penggunaan media ular tangga tentang kemampuan kognitif mahasiswa terhadap materi strategi pembelajaran mata kuliah Pendidikan PKN SD semester 2 STKIP Bina Insan Mandiri.Teknik pengumpulan data berupa tes kognitif, observasi dan catatan lapangan.Aktivitas siklus I skor rata-rata 2,96 dikategorikan cukup persentase keberhasilannya sebesar 74,03\%. Aktivitas mahasiswa siklus II skor rata-rata 3,05 dikategorikan baik dan persentase keberhasilan $76,44 \%$. Pada siklus III aktivitas mahasiswa meningkat rata-rata 3,27 dikategorikan sangat baik dan persentase keberhasilan 81,73\%. Hasil belajar kognitif mahasiswa observasi awal rata-rata kelasnya 46,91. Pada siklus I rata-rata kelas sebesar 52,57, pada siklus II ratarata kelas 70,14 dan siklus III rata-rata kelas 84,84. Hal ini menunjukkan peningkatan hasil belajar kognitif mahasiswa dari awal sampai siklus III.yaitu persentase keterlaksanaan pembelajaran 97\%. Hasil siklus III memenuhi keberhasilan.Jadi disimpulkan hasil belajar kognitif mahasiswa STKIP Bina Insan Mandiri materi Strategi Pembelajaran terjadi ketuntasan belajar dan setiap siklus mengalami peningkatan.
\end{abstract}

Kata Kunci : Media ular tangga, Pendidikan PKN SD, Strategi Pembelajaran, Kemampuan kognitif mahasiswa

\begin{abstract}
This research is about increasing the use of snake media about students' cognitive ability toward the subject matter teaching materials PKN SD semester 2 STKIP Bina Insan Mandiri. Data collection techniques include cognitive tests, observations and field notes. Activity cycle I average score of 2.96 is categorized quite a success percentage of 74.03. Student activity cycle II average score of 3.05 is categorized good and the percentage of success is 76,44\%. In the third cycle of student activity increased an average of 3.27 is categorized excellent and the percentage of success is $81.73 \%$. The cognitive learning outcomes of the students of the initial observation average of the class is 46,91 In the first cycle of the class average is 52, 57. in cycle II average class 70,14 and cycle II average class 84,84. This shows the improvement of cognitive learning outcomes of students from the beginning to the third cycle is the percentage of learning execution 97\%. The results of cycle III meet the success. So concluded the cognitive learning outcomes of students STKIP Bina Insan Mandiri Learning strategy material there is mastery learning and every cycle has increased.
\end{abstract}

Keywords : Ladder snake media, PKN SD Education, Learning Strategy, Student cognitive ability. 


\section{PENDAHULUAN}

Pendidikan merupakan suatu belajar pengetahuan, keterampilan, dan kebiasaan sekelompok orang yang diturunkan dari satu generasi ke generasi berikutnya melalui pengajaran, pelatihan, atau penelitian.Dalam pendidikan yang sering terjadi di bawah bimbingan orang lain. Setiap pengalaman yang memiliki efek formatif pada cara orang dalam berpikir, merasa, atau bertindak dapat dianggap pendidikan.

Sebagian orang memahami arti pendidikan sebagai pengajaran yang telah didapatkan dari lembaga pendidikan pada waktu di sekolah, madrasah, dan perguruan tinggi.Pendapat tersebut tidak dapat dianggap salah karena pada kenyataannya, seseorang mendapatkan ilmu pengetahuan melalui lembaga pendidikan tersebut. Pendidikan merupakan proses pengubahan sikap dan tata laku seseorang atau kelompok orang dalam usaha mendewasakan manusia melalui upaya pengajaran.

Peningkatan kualiatas pendidikan merupakan suatu proses yang terintegrasi dengan proses peningkatan kualitas sumber daya manusia itu sendiri. Kemajuan ilmu pengetahuan dan teknologi yang pesat menuntut sumber daya manusia yang berkualitas.Peningkatan sumber daya manusia merupakan syarat untuk mencapai tujuan pembangunan.Salah satu wahana untuk meningkatkan sumber daya manusia adalah pendidikan yang berkualitas yang diupayakan dengan berbagai program pendidikan yang mengacu pada kemajuan IPTEK.

Menurut Syaiful Bahri Djamarah (2002:168), dalam dunia pendidikan ada tiga tujuan pendidikan yang sangat dikenal dan diakui oleh para ahli pendidikan, yaitu ranah kognitif, ranah afektif, dan ranah psikomotorik. Ranah kognitif merupakan kemampuan yang selalu dituntut kepada peserta didik untuk dikuasai, karena penguasaan kemampuan pada tingkatan ini menjadi dasar bagi penguasaan ilmu pengetahuan.

Dalam pendidikan, kemampuan kognitif dapat diukur menggunakan prestasi belajar. Menurut Nana Sudjana (2005:50) "Ada tiga ranah (domain) hasil belajar, yaitu ranah afektif, ranah psikomotorik, dan ranah kognitif". Dari prestasi belajar dapat diketahui tingkat keberhasilan kemampuan kognitif seseorang.Kemampuan kognitif adalah proses mengolah informasi yang menjangkau kegiatan kognisi, intelegensia, belajar, pemecahan masalah dan pembentukan konsep. Secara lebih luas menjangkau kreativitas, imajinasi dan ingatan.Pada dasarnya kemampuan kognitif merupakan hasil belajar.Sebagiamana diketahui bahwa hasil belajar merupakan perpaduan antara faktor pembawaan dan lingkungan (faktor dasar dan ajar).

Menurut Sanjaya, (2007 : 126). Dalam dunia pendidikan, strategi diartikan sebagai perencanaan yang berisi tentang rangkaian kegiatan yang didesain untuk mencapai tujuan pendidikan tertentu.Sedangkan Kemp (1995) menjelaskan bahwastrategi pembelajaran adalah suatu kegiatan pembelajaran yang harus dikerjakan guru dan siswa agar tujuan pembelajaran dapat dicapai secara efektif dan efisien.

$$
\text { Pada pengertian diatas dapat disimpulkan bahwa strategi }
$$

pembelajaran merupakan suatu rencana tindakan (rangkaian kegiatan) yang termasuk juga penggunaan metode dan pemanfaatan berbagai sumber kekuatan dalam 
pembelajaran.Demikian di dalam penyusunan suatu strategi baru sampai pada proses penyusunan rencana kerja belum sampai pada tindakan. Strategi disusun untuk mencapai tujuan tertentu, artinya disini bahwa arah dari semua keputusan penyusunan strategi adalah pencapaian tujuan, sehingga penyusunan langkah-langkah pembelajaran, pemanfaatan berbagai fasilitas dan sumber belajar semuanya diarahkan dalam upaya pencapaian tujuan.Namun sebelumnya perlu dirumuskan suatu tujuan yang jelas yang dapat diukur keberhasilannya.

Salah satu upaya untuk meningkatkan kemampuan kognitif mahasiswa dalam mata kuliah Pendidikan PKN SD adalah media pembelajaran.Para dosen dituntut agar mampu menggunakan alat-alat yang disediakan di perguruan tinggi dan tidak tertutup kemungkinan alat tersebut sesuai dangan perkembangan dan tuntutan zaman.Dosen sekurang-kurangnya dapat menggunakan alat-alat yang tersedia, selain itu juga dituntut untuk dapat mengembangkan keterampilan membuat media pembelajaran sendiri.

Media pembelajaran diklasifikasikan menjadi beberapa sudut pandang, yaitu : (1) media auditif, yaitu media yang hanya dapat didengar saja, dan media yang hanya memiliki unsur suara, (2) media visual, yaitu media yang hanya dapat dilihat saja tidak mengandung unsur suara, contohnya film slide, foto, transparansi, lukisan, gambar, (3) media audio visual, yaitu jenis media yang selain mengandung unsur suara juga mengandung unsur gambar yang dapat dilihat (Sanjaya,2009).

Rustaman (2005) menyatakan bahwa media pembelajaran merupakan bagian integral dari proses belajar mengajar yang bertumpu pada tujuan, materi, metode, dan evaluasi pembelajaran. Sedangkan Aqib (2002), menyatakan bahwa media diartikan sebagai segala sesuatu yang dapat digunakan untuk menyampaikan atau menyalurkan pesan (message) merangsang pikiran, perasaan, perhatian, dan kemauan siswa sehingga dapat mendorong proses pembelajaran.

Media pembelajaran adalah alat bantu dalam proses belajar mengajar. Sesuatu apapun yang dapat dipergunakan untuk merangsang pikiran, perhatian, perasaan, dan kemampuan atau keterampilan pembelajar tersebut sehingga dapat mendorong terjadinya proses belajar atau kegiatan pembelajaran.Pada zaman dulu kebanyakan anak di Indonesia bermain permainan ular tangga yang terbuat dari kertas dengan menggunakan dadu sebagai penentu jalannya permainan ini di dalam setiap kotak terdapat angka 1-30 dan tak lupa ada ular dan ada tangga.Permainan ini menjadi sangat populer di masyarakat khususnya dikalangan anak kecil zaman dahulu, kini permainan ular tangga, meski telah dikemas lebih modern menggunakan berbagai petak dengan ukuran berbeda serta bidak dengan tambahan magnet, namun keberadaannya sudah semakin menghilang.Dengan adanya permainan yang instan dan semakin canggih misalnya menggunakan komputer maupun handphone maka permainan ini semakin musnah.Maka dari itu dosen berinisiatif menghidupkan permainan lama menjadi permainan yang sangat diminati oleh mahasiswa sebagai media pembelajaran.

Dengan sistem pembelajaran yang modern ini, mahasiswa tidak hanya berperan sebagai komunikan atau penerima pesan, tetapi juga bisa bertindak sebagai komunikator atau penyampaian pesan.Dengan adanya komunikasi dua arah maka media memperoleh 
efektifitas pencapaian tujuan atau kompetensi dalam pembelajaran. Proses pembelajaran akan terjadi apabila ada komunikasi antara penerima pesan dengan sumber atau penyalur pesan lewat media ular tangga tersebut.

Rendahnya kemampuan mahasiswa menjadi petunjuk adanya kecenderungan kelemahan sekaligus kesulitan belajar, yang dalam hal ini berarti ada kesulitan menerima pembelajaran.Dengan aktivitas dan permainan yang monoton serta penggunaan metode yang cenderung hafalan dan dengan pemberian tugas berakibat kemampuan mahasiswa dalam memahami suatu materi yang disampaikan masih rendah. Dengan demikian akan membuat mahasiswa kurang mengembangkan kemampuan kognitifnya. Karena mahasiswa memiliki anggapan bahwa bermain dengan alat permainan merupakan permainan yang sulit dan tidak disukai.Sementara itu, selama ini dosen masih kurang optimal dalam menyampaikan pembelajaran.Agar materi pembelajaran yang disampaikan dosen kepada mahasiswa lebih mudah diterima maka dosen perlu melakukan tindakan-tindakan tertentu yang dirasa perlu untuk meningkatkan kemampuan mahasiswa dalam memahami suatu materi pembelajaran.

Peranan media pembelajaran sangatlah penting dalam memperkuat penyampaian pesan-pesan dalam proses pembelajaran. Media ular tangga pada umumnya terdiri atas satu petak permainan yang berisi kotak-kotak yang harus dilewati oleh para pemain dengan menggerakan bidak setelah sebelumnya memutar dadu terlebih dahulu. Bisa dilihat bahwa permainan ular tangga tradisional ini ringan (mudah dimengerti), sederhana peraturannya, mendidik dan menghibur anak-anak dengan cara yang positif dan sangat interaktif.

Strategi pembelajaran lebih berkenaan dengan pola umum dan prosedur umum aktivitaspembelajaran, sedangkan desain pembelajaran lebih menunjuk kepada cara-cara merencanakan suatu sistem lingkungan belajar tertentu setelah ditetapkan strategi pembelajaran tersebut. Berdasarkan uraian di atas, bahwa untuk dapat melaksanakan tugasnya secara profesional, seorang dosen dituntut dapat memahami dan memliki keterampilan yang memadai dalam mengembangkanberbagai model pembelajaran yang efektif, kreatif dan menyenangkan.

Mahasiswa dipandang mempunyai tingkat kedewasaan yang lebih dari siswa, karena rata-rata usia mahasiswa adalah 18 tahun keatas. Tuntutan penguasaan kemampuan kognitifnya juga lebih besar dibandingkan dengan siswa. Saat masih menjadi siswa, ranah kognitif masih dalam tahap perkembangan dasar, sedangkan mahasiswa pada ranah tersebut dianggap sudah memiliki kemampuan yang dikuasai untuk dikembangkan dan diaplikasikan dalam suatu profesi di masa depan. Konsep peningkatan mutu pendidikan merupakan titik pusat manajemen peningkatan mutu berbasis kuliah.Konsep peningkatan mutu berbasis kuliah ini menekankan kemandirian dan kreativitas di area perguruan tinggi. Adapun mutu peningkatan mutu ini hanya di lihat dari hasil yang dicapai oleh mahasiswa saja, tetapi dimulai dari proses pembelajarannya.

Dosen merupakan faktor penentu yang sangat dominan dalam pendidikan pada umumnya, karena dosen memegang peranan dalam proses pembelajaran, di mana proses 
pembelajaran merupakan inti dari proses pendidikan secara keseluruhan (Rusman, 2013: 58). Peran dosen adalah seorang pendidik, pembimbing, pelatih dan pengembang kurikulum dengan menciptakan kondisi dan suasana belajar yang kondusif, yaitu suasana belajar yang menyenangkan, menarik, memberi rasa aman, memberikan ruang pada mahasiswa untuk berpikir aktif, kreatif dan inovatif dalam mengeksplorasi dan mengelaborasi kemampuan (Rusman, 2013: 19). Berdasarkan hal ini dosen harus dapat melaksanakan proses pembelajaran Pendidikan Kewarganegaraan SD menjadi menyenangkan untuk dipelajari dengan menggunakan strategi pembelajaran yang aktif serta bervariasi agar aktivitas belajar mahasiswa menjadi lebih baik lagi dan tujuan pembelajaran akan tercapai.

Upaya dalam peningkatan sarana dan prasarana sekolah, sertifikasi pendidik dan dosen, peningkatan kesejahteraan pendidik dan dosen, serta mendorong inovasi-inovasi dalam pembelajaran melalui kegiatan pelatihan-pelatihan, termasuk dalam program studi Pendidikan Guru Sekolah Dasar khususnya pada pembelajaran Pendididkan PKN SD yang mengharuskan untuk menyelipkan media pembelajaran agar kemampuan kognitif mahasiswa bisa berjalan. Namun, kenyataan yang ada pada saat ini terdapat beberapa kelemahan yang terkait dengan proses pembelajaran.Oleh karena itu dosen sebagai peneliti untuk menggunakan media pembelajaran yang berbasis ular tangga untuk memberikan kemampuan kognitif siswa agar pembelajaran bisa menyenangkan dan tidak terpaku hanya dalam penjelasan dosen saja tetapi langsung pada prakteknya.

Di dalam kurikulum program studi PGSD di STKIP Bina Insan Mandiri selain membekali mahasiswa dengan ilmu pendidikan dan pengajaran tetapi juga dengan keahlian untuk praktek yang nantinya dapat digunakan untuk membekali mahasiswa ketika mendapat mata kuliah microteaching pada semester mendatang. materi yang menunjang di bidang Pendidikan PKN SD ini adalah salah satunya untuk mengenal dasar-dasar dari model,strategi, pendekatan dan media pembelajaran yang diterapkan ketika dimulai praktek pengajaran sebagai salah satu pengevaluasian untuk tugas akhir pada perkuliahan.

Pada kegiatan penelitian tersebut menunjukkan bahwa dalam proses pembelajaran materi strategi pembelajaran pada Pendidikan PKN SD masih belum maksimal, hal ini disebabkan karena sebagian mahasiswa yang kemampuan kognitifnya masih rendah, minat dan perhatiannya kurang terhadap materi yang dijelaskan oleh dosen. Adanya masalah dalam proses perkuliahan ini membuat penulis tertarik untuk mengangkatnya dalam sebuah penelitian yang bersifat ilmiah dengan judul "Peningkatan Dalam Penggunaan Media Ular Tangga Mata Kuliah Pendidikan PKN SD Materi Strategi Pembelajaran Pada Kemampuan Kognitif Mahasiswa Semester 2 STKIP Bina Insan Mandiri Surabaya"

\section{METODE PENELITIAN}

Jenis penelitian yang digunakan penulis adalah jenis penelitiantindakan kelas (PTK) dan istilah dalam bahasa inggris adalah Classroom Actions Research (CAR).Penelitian deskriptif kuantitatif dilaksanakan untuk mengolah data yang 
diperoleh dari hasil tes terhadap kemampuan kognitif mahasiswa dalam mata kuliah Pendidikan PKN SD. Penelitian ini menggunakan rancangan Penelitian Tindakan Kelas (PTK) kolaboratif yang bersiklus.Setiap siklusnya selalu menempuh empat tahap, yaitu perencanaan (planning), pelaksanaan (acting), pengamatan (observing), dan refleksi (reflecting).Keempat tahapan tersebut dilaksanakan secara berulang dalam bentuk siklus hingga seluruh indikator tercapai. Penelitian ini dilaksanakan untuk memecahkan permasalahan yang terjadi dalam proses pembelajaran di kelas. Dengan adanya pelaksanaan PTK ini diharapkan dapat memperbaiki dan meningkatkan mutu proses dan hasil pembelajaran, memperbaiki dan meningkatkan prestasi belajar mahasiswa, serta perbaikan dan peningkatan materi dan cara pembelajaran di kelas.

Berdasarkan hasil refleksi siklus pertama, akan diketahui kelemahan dan kekurangannya. Berdasarkan hal itu, selanjutnya peneliti dan sejawat merencanakan tindakan siklus kedua.Kemudian dosen menerapkannya melalui pembelajaran di dalam kelas, lalu di amati dan diadakan refleksi. Bila dari hasil siklus kedua ini ada indikator yang belum dicapai, maka direncanakan tindakan siklus berikutnya sampai semua indikator yang telah ditentukan tercapai, baru siklus tindakan diakhiri.

Dalam pelaksanaannya, Penelitian Tindakan Kelas (PTK) ini menggunakan model Kurt Lewin, yang menyatakan bahwa satu siklus terdiri dari empat langkah pokok yaitu: (1) perencanaan (planning), (2) aksi atau tindakan (acting), (3) observasi (observing) dan, (4) refleksi (reflecting).

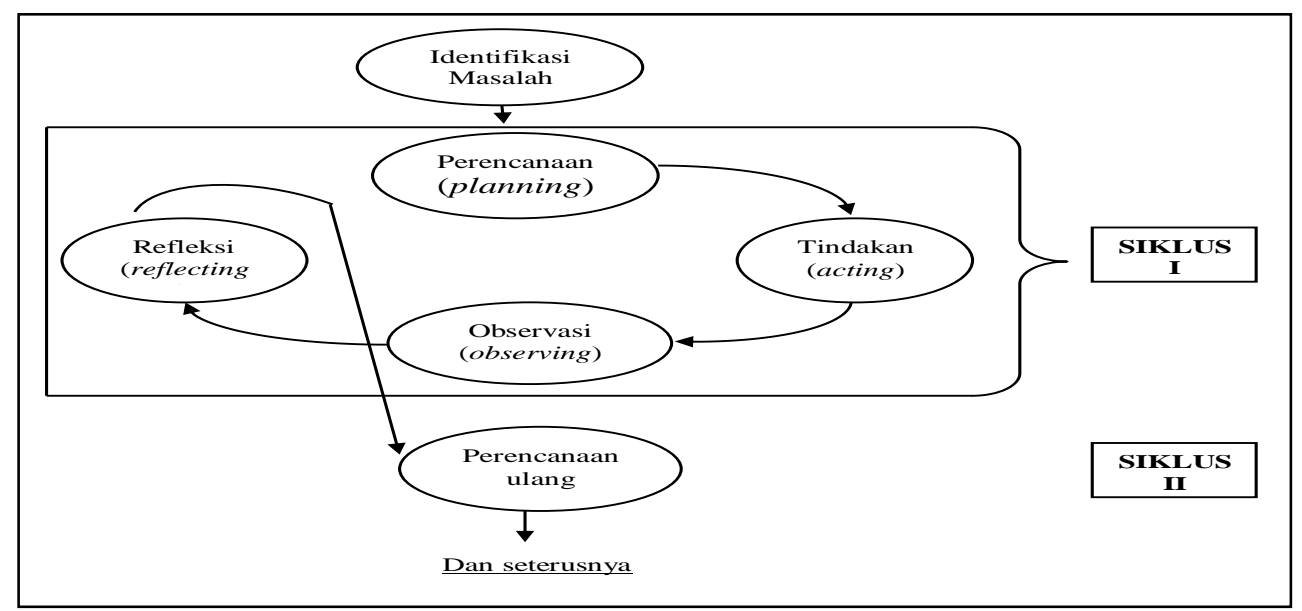

Gambar1. Prosedur Model Kurt Lewin

Sumber: Modul PTK, 2007

Penelitian Tindakan kelas (PTK) ini dilakukan di STKIP Bina Insan MandiriSurabaya.Subjek penelitian ini adalahmahasiswa semester 2 Program Studi PGSD yang berjumlah 34 mahasiswa.Penelitian ini dilaksanakan di Perguruan Tinggi STKIP Bina Insan Mandiri Surabaya Masalah yang ditemukan oleh peneliti yaitu dosen meggunakan ceramah dalam pembelajaran dan seringkali yang dipakai oleh dosen yaitu metode diskusi setiap kelompok yang membuat mahasiswa jenuh serta menyebabkan mahasiswa kurang memahami materi pembelajaran tersebut.Kemudian kurang adanya 
motivasi dari dosen dalam menggunakan media yang membuat kemampuan kognitif mahasiswa berkembang sehingga proses kegiatan pembelajaran terasa kurang aktif dan kreatif. Mahasiswa terlihat diam dan monoton, serta malas memperhatikan dosen.

Berdasarkan observasi yang dilakukan oleh peneliti terhadap mahasiswa, peneliti bersama teman sejawat berdiskusi untuk mencari solusi yang tepat agar pembelajaranmata kuliah Pendidikan PKN SD secara menarik, mahasiswa bersemangat dan bergairah untuk belajar dan memperhatikan penjelasan dosen terhadap media pembelajaran, mahasiswa berkesempatan untuk mengkomunikasikan ide atau gagasan baik kepada dosen maupun kepada temannya tentang topik yang dibahas dalam pembelajaran, berani bertanya serta mengungkapkan dan bertukar pendapat dan menjawab pertanyaan dari dosen melalui media ular tangga yang dimainkan. Oleh karena itu, dari hasil media ular tangga tersebut telah disepakati untuk mengadakan tindakan perbaikan pada mata kuliahstrategi pembelajaran melalui media ular tangga.

Hasil pengamatan aktivitas dosen diperoleh dari pelaksanaan pembelajaran di kelas.Data penelitian ini diambil sesuai dengan Rancangan Pelaksanaan Pebelajaran (RPP) yang telah dibuat.Hasil pengamatan aktivitas mahasiswa ini diperoleh selama proses pembrlajaran dikelas. Dimana aspek yang diamati meliputi kegiatan kemampuan dan kreativitas mahasiswa dalam melakukan kegiatan permainan ular tangga.Hasil kegiatan pembelajaran mahasiswa diperoleh setelah memperoleh kegiatan Pendidikan PKN SD. Hasil belajar ini diberikan dalam tes soal tertulis yang sesuai dengan kegiatan mahasiswa di kelas.Hasil wawancara diperoleh pada saat terjadinya proses belajar mengajar pada setiap siklus. Adapun indikator keberhasilan dalam penelitian ini adalah 1) ketercapaian pelaksanaan pembelajaran oleh dosen dalam pembelajaran dengan menggunakan media ular tangga yang dalam pengamatan mencapai skor $>80$ (Arikunto, 1993:249).

\section{HASIL DAN PEMBAHASAN}

Sebelum melaksanakan tahapan-tahapan pada siklus I, maka terlebih dahulu peneliti melakukan observasi dan wawancara dengan dosenPGSD dengan mahasiswa semester 2 untuk menemukan permasalahan-permasalahan dalam pendidikan PKN SD STKIP Bina Insan Mandiri Surabaya. melalui wawancara dengan dosen, diketahui pula bahwa dari 34mahasiswa semester, terdapat 23 siswa yang mendapatkan nilai di bawah kriteria yang ditentukan oleh dosen PGSD $(\geq 80)$ untuk materi Strategi Pembelajaran.

Setelah peneliti menemukan permasalahan yang terdapat dalam materi strategi pembelajaran, peneliti melakukan tahapan perencanaan sebagai berikut: menentukan waktu penelitian; menganalisis kurikulum; membuat Rencana Pelaksanaan Pembelajaran (RPP); mempersiapkan media pembelajaran; membuat Lembar Kegiatan Siswa (LKS), Lembar Penilaian, lembar observasi aktivitas guru, dan lembar catatan lapangan. Setelah tahap perencanaan selesai, peneliti melakukan tahap pelaksanaan pembelajaran dengan menggunakan media ular tangga, disertai tahap pengamatan yang dilakukan oleh dua observer dengan mengisi lembar observasi aktivitas guru dan catatan lapangan. 
Data penelitian yang disajikan dalam bab ini adalah hasil Penelitian Tindakan Kelas (PTK) yang dilaksanakan di semester 2 angkatan tahun 2016-2017 STKIP Bina Insan Mandiri. Adapun jenis data penelitian PTK tersebut meliputi data hasil temuan awal dan data pelaksanaan Penelitian Tindakan Kelas (PTK). Data pelakasanaan PTK terdiri dari tiga siklus dan setiap siklus disajikan dalam beberapa siklus yang terdiri dari 4 (empat) tahap sebagai berikut: (a) perencanaan, (b) tindakan, (c) observasi, (d) refleksi.

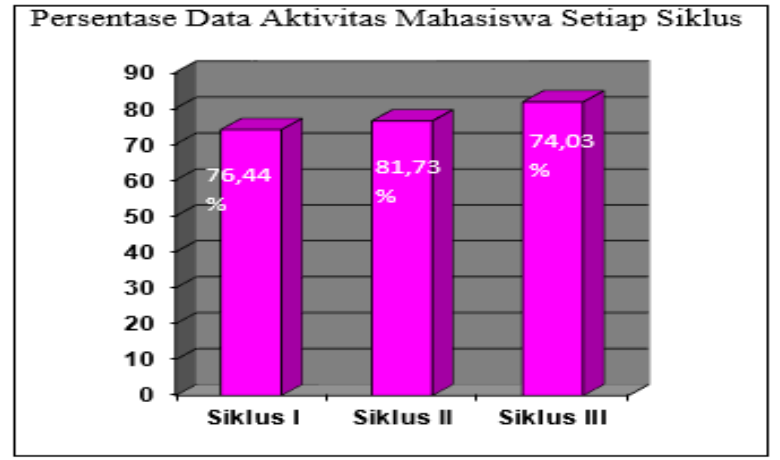

Gambar 2. Presentase Data aktivitas mahasiswa setiap siklus

Berdasarkan diagram diatas, diketahui bahwa aktivitas mahasiswa dalam pembelajaran mata kuliah Pendidikan PKN SD dengan penerapan media ular tangga dari siklus I hingga siklus III mengalami peningkatan. Aktivitas mahasiswa pada siklus I memperoleh skor rata-rata 2,96 dikategorikan cukup dengan persentase keberhasilan sebesar 74,03\%. Aktivitas mahasiswa pada siklus II memperoleh skor rata-rata 3,05 dikategorikan baik dan mencapai persentase keberhasilan sebesar 76,44\%. Pada siklus III aktivitas mahasiswa meningkat dengan skor rata-rata 3,27 dikategorikan sangat baik dan mencapai persentase keberhasilan sebesar 81,73\%.

Meningkatnya aktivitas mahasiswa semester 2 STKIP Bina Insan Mandiri Surabaya dalam bertanya, menjawab pertanyaan dari dosen berbagi dengan keseluruhan kelas, mengerjakan evaluasi secara mandiri, dan bekerja sama dalam kelompok tentunya karena dosen dalam melakukan proses belajar mengajar menggunakan media ular tangga.

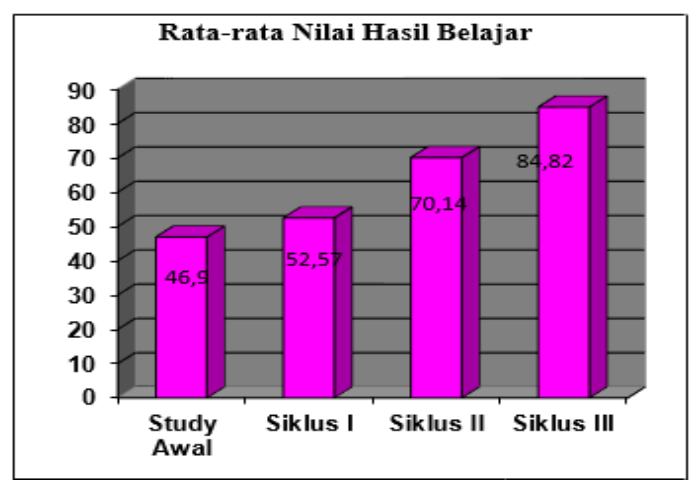

Gambar 3. Diagram nilai hasil belajar Mahasiswa 
Dari hasil belajar kognitif mahasiswa pada mata kuliah pendidikan PKN SD dapat disimpulkan bahwa terdapat peningkatan hasil belajar yang menunjukkan bahwa media ular tangga sangat efektif untuk diterapkan.Penerapan media ular tangga memberikan kesempatan mahasiswa untuk menguasai macam-macam permainan yang digunakan dalam pembelajaran baik disekolah maupun diluar sekolah.Sehingga membuat mahasiswa lebih mudah dalam melakukan permainan dalam pembelajaran.

\section{KESIMPULAN DAN SARAN}

Berdasarkan rumusan masalah dan hasil penelitian yang telah dibahas pada bab sebelumnya, maka dapat disimpulkan bahwa:

1. Aktivitas yang dilakukan oleh dosen dengan menggunakan media ular tangga terhadap matakuliah pendidikan PKN SD materi Strategi Pembelajaran semester 2 STKIP Bina Insan Mandiri terjadi peningkatan. Peningkatan yang paling menonjol adalah pada aktivitas di saat dosen melakukan pembukaan pembelajaran, penyajian materi, membagi Tugas, melakukan bimbingan, meminta mahasiswa mempresentasikan hasil diskusi,memberikan penghargaan dan evaluasi. Rata-rata aktivitas dosen juga mengalami peningkatan.

2. Aktivitas mahasiswas emester 2 STKIP Bina Insan Mandiri selama pembelajaran dengan menggunakan media ular tangga materi Strategi Pembelajaran terjadi peningkatan. Peningkatan yang paling menonjol adalah aktivitas di saat mahasiswa mengetahui tujuan pembelajaran, menerima tugas, menerima penghargaan dan mengerjakan evaluasi. Rata-rata aktivitas mahasiswa juga mengalami peningkatan.

3. Tes hasil belajarmahasiswa semester 2 pada materi pokok strategi pembelajaran.Nilai ketuntasan belajar setiap siklus juga terjadi peningkatan.

Media ular tangga adalah salah satu media yang dapat digunakan untuk meningkatkan penguasan konsep mahsiswa. Media ular tangga dapat digunakan untuk mengajarkan pada materi lain yang berhubungan dengan penguasaan konsep.

\section{DAFTAR PUSTAKA}

Arikunto, Suharsimi.(1993). Manajemen Penelitian. Jakarta: Raja Grafindo.

Arikunto, Suharsimi. (2010). Prosedur Penelitian: Suatu Pendekatan Praktik. Jakarta: Rineka Cipta.

Aqib, Z. (2002). Profesional Guru dalam Pembelajaran. Surabaya: Insan Cendekia.

Djamarah, S.B. \& Zain, A. (2010).Strategi Belajar Mengajar. Jakarta: Rineka Cipta.

Noor, J. 2011. Metodologi Penelitian: Skripsi, Tesis, Disertasi, dan Karya Ilmiah. Jakarta: Kencana Prenada Media Group.

Rusman.(2013). Model-Model Pembelajaran Mengembangkan Profesionalisme dosen. Jakarta : Rajawali Persada.

Sanjaya.(2009). Perencanaan dan Desain Sistem Pembelajaran. Jakarta: Kencana Perdana Media Group.

Sudibyo, Elok. (2009). Model Pembelajaran Inovatif. Surabaya: UNESA.

Sudjana, N. (2012). Penilaian Hasil Proses Belajar.Mengajar. Bandung: PT. Remaja Rosdakarya. 